\title{
Conservation of culturally significant mechanical signal boxes: Should they be considered as being historic buildings or a part of wider railway heritage?
}

Received (in revised form): 29th October 2009

\begin{abstract}
Simon Mclean
is a practicing Chartered Building Surveyor and Senior Lecturer in Building Surveying at Sheffield Hallam University. He has a passion for building conservation and undertook a Master's degree in the Conservation of Historic Buildings at the University of York. While completing his Master's thesis he became involved, through sponsorship from the National Railway Museum in York, in a study relating to the plight of the many historic mechanical signal boxes being rendered redundant by modern electronic signalling. This generated an interest that has endured.
\end{abstract}

Correspondence: Simon Mclean, Sheffield Hallam University, Howard Street, Sheffield S1 1WB, UK.

ABSTRACT Mechanical signal boxes originated from the $1850 \mathrm{~s}$ and were once plentiful. Many are now redundant or have disappeared.Signal boxes are considered culturally significant, hence some boxes are statutorily protected. Listed Building Consent is often guided by the adoption of a standard international conservation philosophy as laid down in the Burra Charter. The main reusers of redundant mechanical signalling are the United Kingdom's many preserved steam railway societies. Actions to listed signal boxes often conflicts with accepted building conservation practice, indicating that signal boxes might be considered a special case. Accepted practice is established by analysis of the terms required for listing buildings, the philosophy proposed by the Burra Charter and the terms of Policy Planning Guidance No.15 in respect of gaining planning permission for changes to historic buildings. Investigation of case studies, visits to preserved steam lines and documented evidence of railway conservator attitudes to signal boxes are used to establish communality or variance from standard building conservation approaches. The article concludes that action to listed signal boxes by preserved railway societies often does not follow standard philosophy. It discusses why that might be so, and if this is because of the signal box's involvement in wider railway operation and position within the larger picture of railway heritage.

Journal of Building Appraisal (2010) 5, 311-320. doi:10.1057/jba.2009.35

Keywords: statutory protection; conservation practice; railway heritage; preserved railways

\section{INTRODUCTION}

Building Surveyors are often called upon to advise clients in respect of treatment of their historic buildings. There are currently over half a million listed buildings in the United Kingdom, so finding that a client's premises are statutorily protected is not likely to 
be a rare occurrence for the practicing surveyor. Listed buildings can be any type of structure from a humble bus shelter to a grand palace, or a 1960s residential block to a 2000-year-old Roman civic building. While three-tier grading of listed structures reflects the perceived value of the individual properties and sites, all listed buildings regardless of grade are subject to the same two legally enforceable criteria. These are that changes that might alter the character of the building can not be made without prior listed building consent (LBC), and that a listed building must be kept in a reasonable state of repair by its owner. Given this standard set of legal preservation requirements across all levels of listed buildings, a surveyor would generally be required to offer advice upon appropriate maintenance and upon potential changes to a listed building, either directly or as part of a larger project. This would particularly be in respect of obtaining LBC or planning permission, and in complying with any conditions required as part of the granting of these applications. The surveyor is aided in predicting responses to submitted applications, given such a variety of ages, sizes, structural types, materials, purposes and locations within the listed building cohort, by one main standardising document. This is the major adopted conservation philosophy laid down by International Council of Monuments and Sites (ICOMoS) in the Burra Charter as first adopted in 1979 and amended in 1999 (ICOMoS, 1999). This charter is adopted as the central philosophy by those who manage the UK's built heritage, and underpins the decisions made in assessing applications for granting LBC, both by local authorities who handle applications for 92 per cent of listed buildings and English Heritage who deal with LBC for the very important listed buildings. Policy Planning Guidance Document (PPG15, 1994), is the document that guides British planning authorities in making decisions in respect of applications for planning permission to change listed buildings. Much of the advice offered in this guide mirrors the philosophy proposed within the Burra Charter. These two documents should make the task of the building and planning surveyor easier as regardless of the nature of the subject listed building any action proposed in a LBC application theoretically needs to reflect the doctrine of the Burra Charter and any planning application needs to be in line with the advice offered by Policy Planning Guidance No.15 (PPG15). However, the author is aware of a type of building where past actions taken in respect of listed examples often appear to contradict the guidelines proposed by the Burra Charter. These buildings are the listed mechanical signal boxes. There were once thousands of individual signal boxes, used to control the flow of traffic across the expanse of the UK's railway network. Sadly due to line closures and electronic signalling many have been rendered redundant or have already been demolished; however, significant numbers remain, of which some are listed.

The author has noted that listed signal boxes have been moved from their original locations, have been re-liveried and changed to match railway lines to which they were never a party. Additionally, they have had their signalling equipment removed and often replaced with an alien frame. These actions are often claimed to be acts of conservation. The author proposes to look at British signal boxes in terms of whether they are buildings in their own right along with the other listed buildings or whether they are, as many railway conservators appear to believe, part of a bigger picture of railway engineering, and as such outside of mainstream building conservation philosophy and practice.

\section{INTRODUCTION TO BRITISH SIGNAL BOXES}

Signal boxes in the United Kingdom evolved from the 1840s. Originally they were just simple shelters for the railway constables who controlled the flow of rail traffic using 
flags and hand-operated signal posts. The widespread introduction of telegraphic equipment and remotely operated signalling using levers and cables that began to be introduced in the 1850s and 1860s, saw the introduction of the fixed and usually elevated signal boxes that we know today (Hamilton, 1959). A signal box was generally engineer-and not architect-designed, and often reflected vernacular styling (SSG, 1986). Relatively few boxes were designed by an architect, and those mostly styled to match a particular station grouping. Railway companies often used standard drawings for building their boxes, with only the length, which depended upon the number of levers required and the spacing between them, being a variation from those drawings. A few boxes such as those at Totton, and at Manchester Road station in Bradford were converted from other structures. The former being a keeper's cottage and the latter a ladies waiting room. The longest recorded signal box structure was the 180 lever box at Shrewsbury Severn Bridge Junction, which extended 29 m (SSG, 1986).

The function of the signal box was three fold. They were needed to house the locking frame that operated the signals and points, and to afford the signalman comfort conditions for long working hours plus give the best available view down the tracks. With the latter consideration, although design form was standard, the height of boxes might vary depending upon local terrain and the presence of obstructions such as bridges. An example of this would be the Monkwearmouth box in the North East whose platform sat $12 \mathrm{~m}$ above the ground. Potential wind damage issues however tended to restrict signal box height and the typical signal box would be around $7.5 \mathrm{~m}$ long, with its working platform $2.4 \mathrm{~m}$ above ground level (SSG, 1986).

Although some locking frames were designed to sit above the signalling platform, these were not popular due to issues of visibility, so the typical box would see the frame housed in a room beneath the platform with the signalman's accommodation sited above. The most popular materials used to construct signal boxes were timber and brick. Many boxes adopted the vernacular beam and post timber style and were cladded in weatherboarding. There are however many examples of stone-built boxes, composite timber and brick boxes, later concrete boxes and even corrugated iron boxes (SSG, 1986). In addition to the architect-designed one-off boxes, it is this variety of designs, the large number of operating railway companies, the variety of materials used, the appearance of vernacular styling and the early date of some boxes, which often leads individual signal boxes to become listed.

To summarise, a typical signal box would be designed primarily for engineering requirements, be built from mass-produced materials and virtually always have a pitched roof. It would typically be two storey with the locking frame housed at ground level and the signalling accommodation on the first floor. Large expanses of glazing would be present to allow maximum vision and an externally located staircase afforded access to the signal platform.

In addition to the structure, a signal box would house an often unique locking frame in terms of manufacturer, date of manufacture and number of levers. This frame converted the pulling motion of the levers in to a horizontal motion to move signals and points on the track. As many boxes were in use 24 hours per day they would contain flues for a fire and a stove, and a sink for signalman comfort. Old boxes would mostly have been retrospectively fitted with electricity and toilet facilities. Signal boxes would contain repeater equipment and telegraphic equipment by which signalmen communicated equipment failures and the location of trains with other signalmen. These instruments would be fixed to the structure along with a unique track diagram. Finally, each box would have its unique records, desk and signalman's furniture and personal equipment 
(Hamilton, 1959). From a purely historic and social perspective, all these elements would count towards preservation of the cultural significance of the signal box (ICOMoS, 1999), and it would be reasonable to conclude that such significance would diminish as elements are removed or changed.

\section{Why signal boxes become listed}

In the latest communications from the departments of Communities and Local Government, circular 01/2007, and Culture Media and Sport, circular PP992, in respect of principles concerning the selection of buildings for listing, set criteria is outlined (DCLG, 2007). These are cited as being architectural interest or historic interest. Within the former of these two categories elements such as architectural design, craftsmanship, decoration, architectural importance, important examples of type and technical innovation are considered significant. In respect of the latter it is historic interest, social interest, economic interest, cultural interest or military interest. This is a narrower band than offered by ICOMoS in the Burra Charter. Departments of Communities and Local Government do however state that significance requires to be manifested in the fabric of the building to justify listing.

Using these criteria, the reasons why a signal box might be listed can be many fold. Firstly, boxes can be listed for architectural or aesthetic reasons. Few signal boxes are architect-designed; however, as icons of railway operation like steam engines they are considered aesthetically pleasing. Vernacular styling is often considered of local importance and signal boxes mostly reflect that style. The aesthetic value can however be compromised by deterioration, vandalism, alterations and redundancy of box and line. Signal boxes were primarily engineering structures and as such could be considered examples of technical innovation. The presence of an original locking frame, some of which are very rare, and its communication equipment would be desirable for an engineering importance to be established. Every signal box has a history and a social value. At the heyday of the railways, there were 13000 working signal boxes, which mean that there were tens of thousands of working signalmen at that time and many currently surviving and interested descendants of signalmen. For historic and social significance to be established a building would typically be expected to remain in its original location. From a listing perspective signal boxes are deemed to be treated like any other building, but their treatment by railway preservation societies and conservators often appears to set them apart.

\section{ICOMOS AND THE BURRA CHARTER}

The Burra Charter first penned in 1979 establishes cultural significance as the catalyst for preservation of a building as a heritage item. ICOMoS state that 'places of cultural significance enrich people's lives'. They further define that cultural significance as being 'aesthetic, historic, scientific, social or spiritual value for past, present or future generations', and qualify cultural significance as being embodied in the place itself, 'its fabric, setting, use, associations, meanings, records, related places and related objects' (ICOMoS, 1999). Using these definitions it can be seen how signal boxes might be considered as culturally significant, but less easy to equate the treatment of some listed and therefore culturally significant signal boxes within the doctrine of ICOMoS. The fabric of a building is defined by ICOMoS as including all the components, fixtures, contents and objects, or in signal box terms, the entire structure, the frame, the equipment and signalmen's effects. In this context, many listed signal boxes lack much of their culturally significant fabric. 


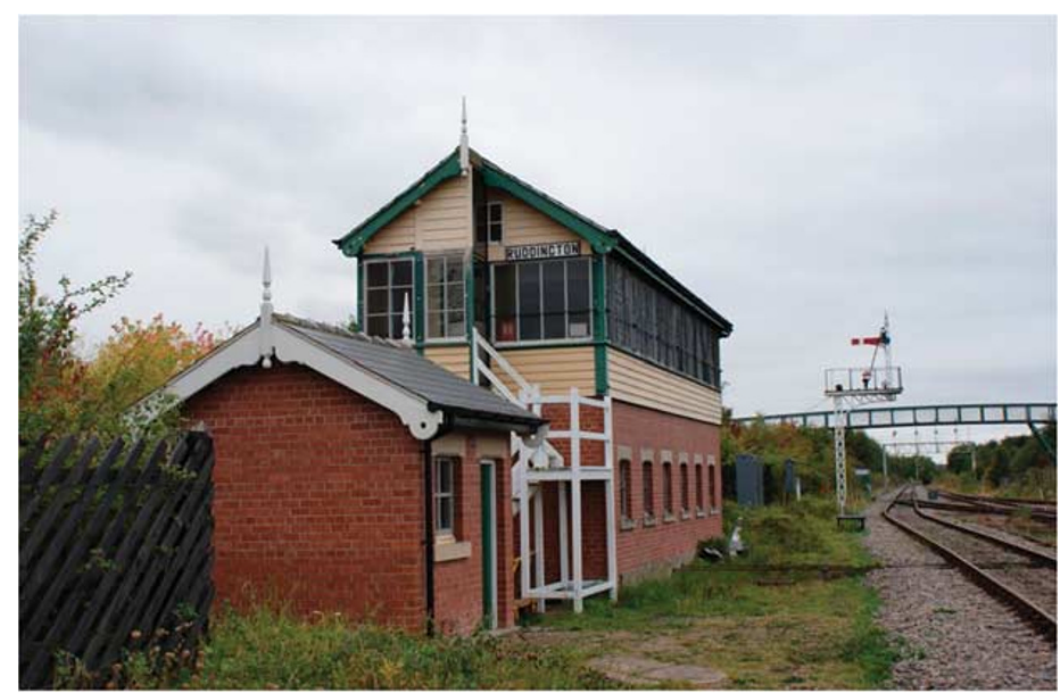

Figure I: Ruddington signal box at the Nottingham transport history centre.

ICOMoS view the establishing and understanding of cultural significance as being the first and primary driver for conservation of a building as required by its listed status. This seems to conflict with the example case studies reviewed later in this work where the box's position in a bigger preserved railway heritage setting appears to override its individual significance as defined by ICOMoS. There is however a caveat within the Burra Charter that conservation interpretation and management of a place should provide for the participation of the people for whom the place has special associations and meanings (ICOMoS, 1999). It could be argued that those associations and meanings in a preserved steam railway context are related to the bigger picture, and that to an ex-signalman the ability to physically work a signal box, albeit with a changed frame outweighs having an original box and frame that can not function in the newly established preserved railway setting. That was indeed the recent opinion of the ex-Nottingham Station signalman who operates the signal box at Ruddington South Junction depot (Figure 1), at the northern end of the preserved Great Central Railway (GCR) steam line in the East Midlands. The shell of that box was relocated from Neasden in London, albeit on an ex-GCR line, and re-fitted with a different frame and communications equipment of undocumented origin. This box is however heralded by the Nottingham Transport Heritage Centre, part of GCR, as being preserved although nothing in the conservation actions taken might match with Burra Charter doctrine.

\section{EXAMPLES OF LISTED SIGNAL BOXES}

\section{Chappel North/Mistley signal box}

The Chappel North signal box is located at Chappel station on the Stour Valley Preserved Railway Line and is a grade II-listed building. It is part of an ensemble of three signal boxes, North, Main and South. South used to be located where North now stands, however this was not its original site as it had been previously relocated from Fotherby Halt in Lincolnshire. North, which is grade II-listed was removed from its original site at 
Mistley in Essex, and transferred to Chappel where it now controls signalling. Main was the original signal box and had its original frame returned to it, however it does not control active signalling being consigned to use as a disconnected museum piece, within the East Anglia Railway Museum operation. The reason cited for relocation from Mistley to Chappel was because the box was at risk (EARM, 2009).

\section{Wellowgate signal box}

Originally built near Grimsby in 1892, this grade II-listed signal box fell redundant in 1994. Network Rail applied for LBC to demolish it. The local authority were reluctant to allow its destruction due to its listed status, but allowed the structure and its frame to be removed to the storage yard at the National Railway Museum (NRM) in York, from where its long term survival would depend upon relocation and restoration in another location; however, 15 years later on the box is still in storage at the NRM, albeit moved from the open yard to covered accommodation. There are no documented plans to reuse this box.

\section{Re-signalling the Wharfedale and Airedale lines}

Nineteen mechanical signal boxes became redundant due to re-signalling. Only one of these boxes attracted listed status, but many were considered of strong local significance. Only four boxes are known to have survived in a railway-related use, and none of those remained in its original location. The Guiseley Junction box built in 1901 was relocated to Bolton Abbey on the Embsay Preserved Steam Line where it was fitted with an electro-pneumatic signalling system from the London Underground and re-liveried. It will be joined at Bolton abbey by an ex-Midland Railway box from Slieghts Sidings East, which is to be fitted out and liveried to match Bolton Abbey's original box as a public attraction. The grade II-listed Keighley Box, built in 1884 and believed to be the oldest surviving Midland Railway signal box, was relocated to another position within Keighley Station, which is shared by Network Rail and The Keighley Worth Valley Steam Railway. The steam railway traffic is however controlled by the box that was relocated from Esholt Junction, on the Airedale line, which coincidentally sits upon the site of the former Keighley West box. Network Rail traffic to the station is controlled by signal box free electronic signalling.

The disused Keighley signal box, despite being listed and being the oldest of its kind, is currently in a very poor condition (Figure 2). Its relocation although only a few yards from the pristine platforms of the Worth Valley Railway is obscured from both commuter rail and steam railway passengers. Passenger attention is now focused upon the newly re-liveried box imported box (Figure 3).

These three case studies, which are not an exhaustive list of similarly treated listed structures, if extended to include signal boxes of historic interest but not actually listed would show a common pattern for the conservation and use of signal boxes that remain in railway use. The strategy, particularly of moving listed buildings away from their sites, changing historic parts of the building and contents and changing the history to match a new setting would conflict with the advice afforded by ICOMoS, in terms of retaining cultural significance. It is however true that most of the signal boxes were redundant and at risk of demolition. The legal penalty of eventual compulsory purchase of a listed building that is being neglected would have little threat to a railway company that did not want to own the listed building. The fact however is that treatment of listed signal boxes by preserved railway companies often mirrors their views of rolling stock and engineering equipment rather than that of a typical historic building. 


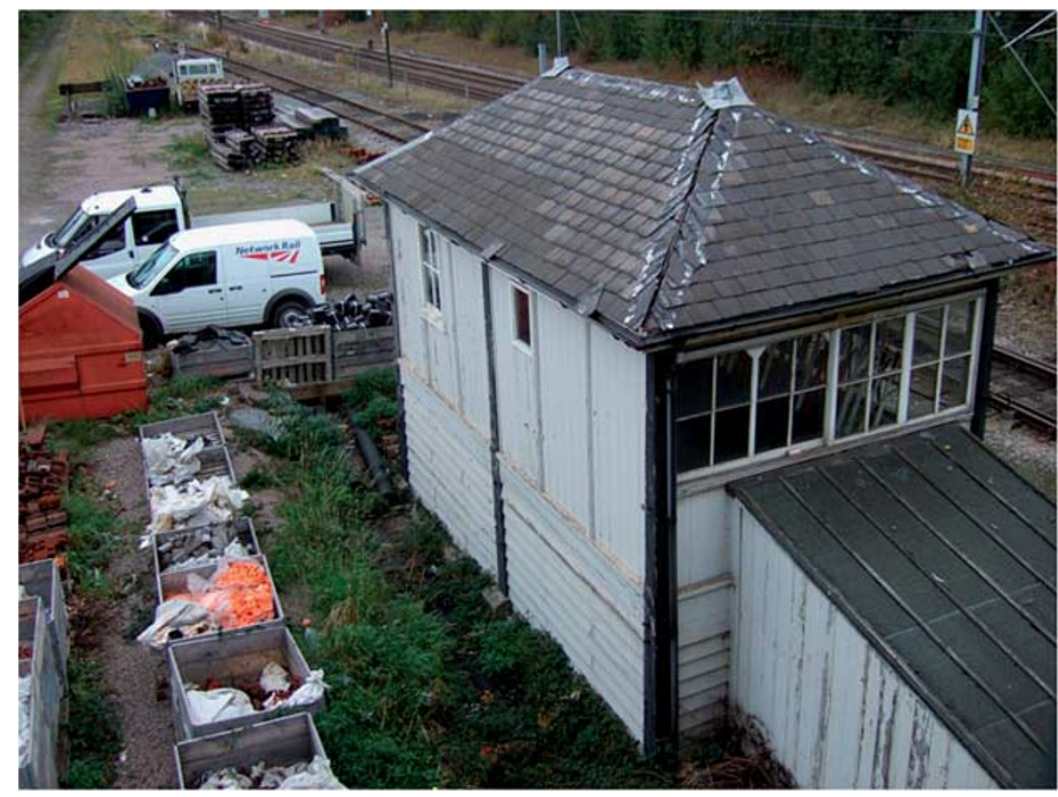

Figure 2: Keighley signal box grade II-listed, but out of use and deteriorating.

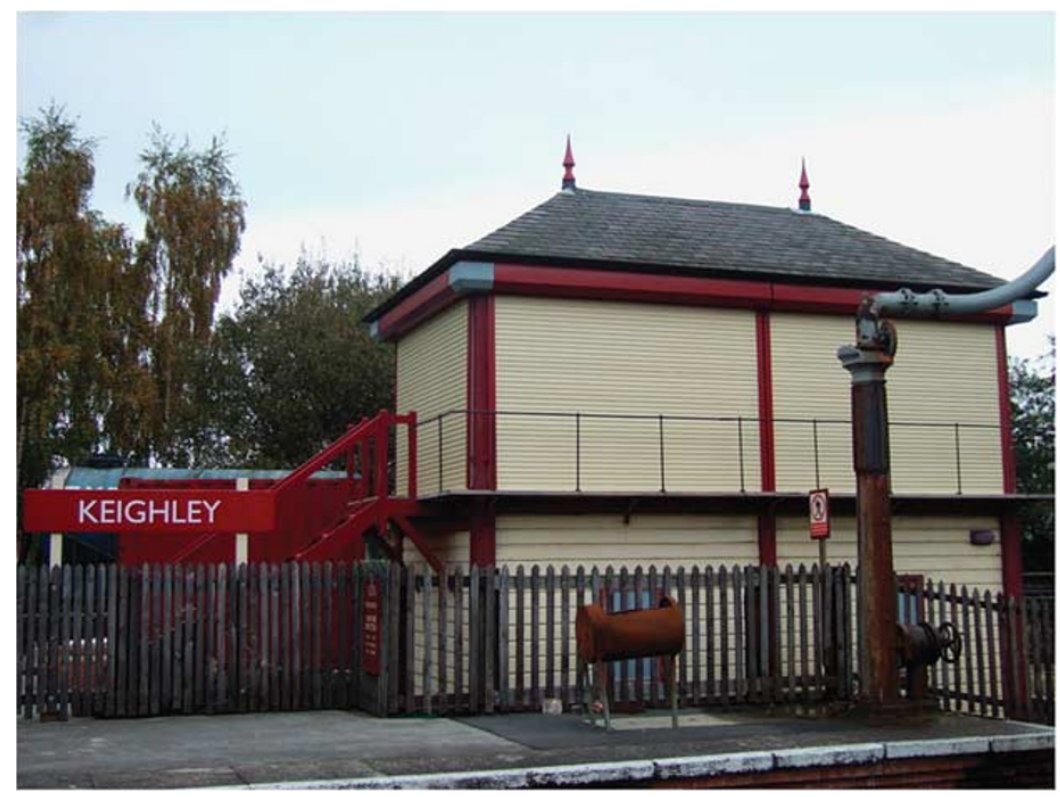

Figure 3: Imported box that controls signalling at Keighley station.

\section{SIGNAL BOXES; HISTORIC BUILDINGS OR PIECES OF RAILWAY EQUIPMENT}

The definition of the position of historic signal boxes in terms of preserved railways is of paramount importance in decision-making terms. They are undoubtedly buildings and also some are subject to statutory legal protection as buildings. A few listed boxes have been preserved and reused, albeit in railway usage terms as redundant buildings. This work is occasionally lottery-funded and usually done very much in line with ICOMoS 
guidelines for conservation of redundant buildings. We must however look at listed Signal Boxes that remain or have the chance to remain in railway use. Although LBC is still required there is no statutory compulsion for the local authority or even English Heritage to follow any common guidelines, even internationally adopted ones, when granting consent.

In 1996, the author undertook a survey of attitudes to historic signal boxes by means of a series of unstructured interviews with senior officers from a number of preserved steam railways, railway museums and signalling preservation societies across England. This study concluded that there was not at that time a common approach to signal box conservation across the railway conservation sector; however, common threads were established. These were a belief that restoration needed to be predominantly aesthetic to compliment the whole railway vista, views that economic criteria needs be paramount as signalling is not the main attraction of steam railways; and an insular vision of railway heritage that often did not extend beyond the boundaries of the particular line or museum site (Mclean, 1996). One important point that came out of this study was a belief that a signal box should ideally remain in a railway context, and even with there being many preserved lines in operation that there be an acceptance that only a small amount of the total number of redundant boxes could be so used. This meant that only the finest examples should be chosen (Mclean, 1996), and perhaps explains why boxes relocate large distances and why listed signal boxes are prized acquisitions. This does mean that listed boxes might be more likely to be chosen for relocation, and suggests a belief that once chosen a listed signal box might by remaining in railway use keep more significance than it would as a redundant building at its original site. The point that many redundant signal boxes are at severe risk in their original locations and would be lost if not removed was also made (Mclean, 1996).

While researching current attitudes to listed signal boxes, no significant difference from 1996 was noted by the author. A recent phenomena in establishing current attitudes not available in 1996 was discovered. With the advent of National Lottery heritage funding preserved steam lines wishing to partake of a grant need to produce a conservation statement. The following example was taken from the statement produced by the Great Western Society Ltd (GWS) for the Didcot Railway Centre located at Didcot railway depot on the Great Western Railway (GWR) line (GWS, 2007), which comprises three-working railway lines, an original grade II-listed engine shed with grade II-listed water tank dating to 1932, and an engine-lifting shop. Buildings transferred to the site from other locations include two signal boxes, brought from Radstock and Frome, and a grade II-listed transfer shed. There are also a number of newer buildings built since the 1980s by GWS to facilitate running the centre as a visitor attraction and for working upon the rolling stock.

Aside from meeting the stereotypical action of bringing in signal boxes and listed buildings as required from remote locations rather than rebuilding their original boxes, the centre also showed an attitude, while enthusiastic in its commitment to conservation excellence, that differed from that advocated by the Burra Charter. GWS in their conservation statement accepted that maintenance and development work done in their early days for operating and economic expediency had resulted in irreversible loss of fabric and damage to the historic significance of some of its buildings. Their solution is however unusual in conservation practice terms. They run the maintenance and development of all built assets new and old from the provisions of the GWR Site Maintenance Code and Minor Works Register, and all painting to the 1933 GWR Engineering Department Instructions for Inspectors and Storekeepers Livery Register 
Number Two, thus effectively positioning all its construction activity to a golden age period. This was cited as providing for the use of better quality traditionally used materials and better levels of workmanship, which would be designed to last. It evidences however a viewpoint focused upon railway engineering practice and the entire site rather than upon the bespoke conservation of individual buildings, which appear perceived as being purely a part contributing to a greater whole. Throughout the conservation statement a constant theme is that this site is about the GWR with an aim is to show the public how that railway ran. It cites doing things in the old GWR way as being good conservation practice, however it appears the undertaking of old practices overrides their value in building conservation, and preserving the practice appears more important than bespoke conservation of individual buildings. Although detailed mention is made of the original listed structures on the site all other capital items both built and rolling appear to be viewed as being part of that larger picture of GWR in operation, which as a museum dedicated to the GWR is not unsurprising, (GWS, 2007).

\section{CONCLUSIONS}

The author started from a point of noting that listed signal boxes often receive treatment that would be very unusual for other categories of listed structures. A previous study of redundant signal boxes by the author had identified that it is the steam railway preservation bodies that are likely to continue mechanical signal box use. These did not at that time view signal box conservation in accepted building conservation philosophy ways. Current research, visits to steam railways in Yorkshire and the East Midlands and examination of a conservation statement produced by a steam railway preservation society identified that signal boxes were still often viewed as being part of the railway's engineering assets and not solely as pieces of built heritage. The practice of moving historic signal boxes and retro-fitting them with alien signalling machinery and an alien livery still prevails. The author however became aware that cultural significance for signal boxes perhaps lies more with their railway heritage and being part of a working railway environment. If this is true then perhaps even moving the redundant Wellowgate box to the storage yard of the NRM, where it is located with other redundant railway equipment while it awaits a railway-based reuse, is a better appreciation of its cultural significance than allowing it to be used for a non-railway related use in situ. That however is a philosophical argument for outside of this article.

It is certain that in cases involving preserved railway operation that listed signal boxes have been subject to action, which might set them apart from other listed buildings, and this was done with LBC. From a surveying perspective this precludes a strategy based purely upon the accepted conservation philosophy of the Burra Charter. For such categories of listed buildings perhaps redundancy enforces a different interpretation of what is truly culturally significant, even if this differs from that which appears on the listing statement. The listing statement was probably penned when the signal box being listed was still in network railway use, and the doctrines of ICOMoS in respect of its preservation were subsequently more directly relevant.

\section{REFERENCES}

\footnotetext{
Departments of Communities and Local Government, DCLG. (2007) Circular 01/2007, Revisions to Principles Concerning the Selection of Buildings for Listing. London: TSO, ISBN978-0117539792.

East Anglia Railway Museum (EARM). (2009) Chappel Signal Boxes, www.earm.co.uk/historical/ signalboxes/php.
} 
Great Western Society, (GWS). (2007) Didcot Railway Centre: Home of the Great Western Society Site Development Programme - Conservation Statement, Document No AM/Conservation Statement - VL - SADG 11331207 DOC, www.didcotrailwaycentre.org.

Hamilton, E. (1959) British Railway History 1877-1947. London: George Allen \& Unwin, ASIN B002AGJMHU. ICOMoS Australia. (1999) The Burra Charter 1999, www.icomos/australia/charter/html.

Mclean, S. (1996) Conserving mechanical signal boxes. Unpublished Masters Degree Thesis, Institute of Advanced Architectural Studies, University of York.

PPG15. (1994) Planning Policy Guidance No 15 Planning and the Historic Environment. London: TSO, ISBN978-0117529441.

Signalling Study Group (SSG). (1986) Signal Boxes a Pictorial History and Guide to Design. Oxford: OPC Railprint. 